\title{
日本語小論文の論理構成の把握と炎の図式表現 Ascertaining and Graphically Representing the Logical Structure of Japanese Essays
}

\author{
石岡 恒憲
Tsunenori ISHIOKA
}

\author{
独立行政法人 大学入試センター \\ The National Center for University Entrance Examinations \\ tunenori@rd.dnc.ac.jp, http://www.rd.dnc.ac.jp/ ${ }^{\text {tunenori/ }}$
}

keywords: constellation graph, information compilation, modality, natural language processing, visualization

\section{Summary}

To more accurately assess the logical structure of Japanese essays, I have devised a technique that uses end-of-sentence modality and demonstrative pronouns referencing earlier paragraphs as new indicators of structure in addition to conjunctive expressions which have hitherto often used for Japanese as well as for European languages. It is hoped that this will yield better results because conjunctive expressions are intentionally avoided in Japanese. I applied this technique to the editorial and commentary (Yoroku) columns of the Mainichi Shimbun newspaper and used it to represent the structure and development of the arguments made by these articles in the form of constellation diagrams which are used in the field of statistics. As a result, I found that this graph is useful in that it enables the overall distribution to be ascertained, and allows the temporal changes in the logical structure of the data in question to be ascertained.

\section{1.はじめ に}

エッセイの自動採点および評価は, 現在 , 教育測定に おける最もホットな話題の一つである. 事実 , 多くの採 点評価システムか開発され，実際に供されている.代表 的なシステムとしては , パイオニアである Project Essay Grade, PEG[Page 66, Page 94] の他, アメリカの 経営大学院への入学試験である Graduate Management Admission Test, GMAT の一部である作文テスト Analytical Writing Assessment, AWA の採点に 2006 年 1 月 まで用いられていた e-rater[Burstein 98, Burstein 03]， 意味的な内容の一致を測定する Intelligent Essay Assessor, IEA[Foltz 99, Landauer 00, Landauer 03], ベイズ 理論を採り入れた BETSY [Rudner 02] , ルール発見ア ルゴリズムに基づく IntelliMetric[Elliot 99, Elliot 03] などがある.コンピュータによるエッセイの自動採点お よび評価は, 評定の系列的効果（ある小論文の評定が答 案の中で何番目に行なわれたかにより評定か変わる)，課 題選択（異なる課題に基づいて書かれた小論文をどう一 元的に評価するか；どのように等化をするか) などの問 題を排除できるだけでなく，採点の手間を大幅に低減し， また対話的な作文指導ができるといった点で，極めて有 効であると考えられている．近年では説明責任といった 点からも重要である.

日本語を処理するシステムとしては, 著者らのグルー
プが最初でかつお光らく現時点で唯一のシステムである Jess (第 41 類，商標登録済) [石岡 03, Ishioka 06] を開 発し,Web (http://coca.rd.dnc.ac.jp/jess/) て公 開するだけでなく，クローズドの環境でも利用できるよ う Windows 版を提供している.我々のシステムについ ては, 2005 年 2 月に朝日新聞の夕刊 1 面トップに掲載 されたことを契機に，弚の後，ニッポン放送，ASAhIパ ソコンでも紹介され，2006 年 6 月には Yahoo! Internet

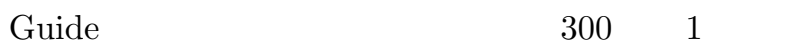
て選定された; 2007 年 2 月には韓国 KBS テレビでも紹 介された . 教育測定の関係者だけでなく，広く一般にも 知られるようになった .

Jess のシステムとしての最大の特徵は, 他の既存のシ ステムがプロの評価者 (rater) を手本にしているのに対 し , このシステムは唯一, プロのライター (writer) の書 いた文章を手本にしているところにある．このため採点 モデルを課題文ごとにセットアップする必要がなく，す なわち採点済みの教師データを必要とせず，従来大規模 な試験にのみしかコスト的に見合わなかったこの分野に おいて, 初めて小規模な試験での運用を可能とした .Jess では, 模範と考えられる小論文/エッセイとしてある全国 誌の新聞における社説とコラム (余録) を学習し, 理想 とする文章の書き方についてのメトリクスの分布を予め 獲得しておく .これらメトリクスの分布のほとんどは左 右非対象の歪んだ分布となるが， この分布を理想とする 
小論文についての分布とみなす . 採点の結果 , 得られた 統計量がこの理想とする分布において外れ值となった場 合に, 弚のメトリクスにおいて「適当でない」と判断し， 割り当てられた配点を減じ，また光の旨をコメントとし て出力する . 外れ值は四分範囲の 1.5 倍を越えるデータ とする

Jess は採点基準については,アメリカの経営大学院 (い わゆるビジネススクール)への入学試験である GMAT に おける AWA の採点基準 [GMA-Council 05] をほぼ踏襲 しており，以下の 3 つの観点から評価を行う .

(1) 修辞:文章としてょく書けているか

(2) 論理構成:アイディアか理路整然と表現されている か.議論が深められているか.

(3) 内容:出題文に適切に応えているか

このうち，(1)の修辞については, 文章の読みやすさ (文の長さ, 句の長さ, 句の数, 埋め込み文の存在等)/語 彙の多樣性/ビッグ・ワード (big word，長くて難しい語) の割合/受動態の文の割合など , 良い文としての指標が比 較的明確で，また光れについての一般的な合意が得られ ている.コンピュータで評価するのに最も適した観点と いうことがいえる．また (3)の内容については，本質的 には困難であるが , 谷の代替として, Latent Semantic Indexing[Deerwester 90] などの手法を採り入れ，いわ ゆる意味的な内容の一致を測定することとしている .こ れは他の多くのシステムでも同樣であり，現時点での技 術レベルでの限界を示しているといえよう .

残る (2) の論理構成については，欧米語に対する多く のシステムでは, 接続表現などの手掛かり語 (cue words) に多く頼っている [Page 94, Burstein 98, Rudner 02] . このため Jess でも，

・順接/逆接を示す手掛かり語の出現の頻度と

・手掛かり語の出現パターンが特異か否か について評価，および判断を行っている.出現パターン の判断については, 順接/逆接の接続表現の出現にトライ グラムモデルを用い, 事前情報なしの場合の生起確率が， (新聞のコラムや社説で予め獲得した) 事前情報ありの生 起確率に比べ大きいならば特異であると判断する．しか しながら，日本語の場合は，接続表現は意識的に避けら れる傾向にある [野矢 97]．実際，この省略が独特のリズ 厶を生み，美文または名文となるからである．事実，毎 日新聞のコラム $($ 余録 $)$ でも， 1 年 365 編のうち, 平均で 20 編は，接続表現の全くない文章である .

もっとも，接続表現の出現個数は, 文章全体の分量に 大きく依存する.コラム $($ 余録) では分量が 700 字である ために，接続表現なしに一つの話題で一気に最後までもつ ていくことが可能であるが , 社説のように 1,200 字とも なると，ある程度の論理構造が必要となり，接続表現な しに書き進めることはできなくなる．しかし不幸なこと に，わが国の大学入試や大学院入試で用いられる小論文 試験では，光の分量はわずか $600 〜 800$ 字程度である .こ
のため, この程度の分量の評価を行うためには，接続表 現だけに頼らない方法で , 全体の論理構造の把握を行う 方法を構築することが必要となる．これについては，た とえば [Reed 01] らの提案する Araucaria では，XML に基づいた AML を用いて記述し，スキーマとして提供 しているが，対話的な文を対象としており，論理的な文 章への適用を想定していないように思われる .

小論文試験は，従来のペーパ一試験ではとらえにくい 思考力・表現力を測る目的で導入する大学が急激に増え， 文部科学省の調べでは 2005 年春の入試で $86 \%$ の国公立 大学が個別試験に取り入れることとしている．私立大学 でも実施する大学が相当数にのぼる．したがって本課題 は喫緊の課題であるといえる .

2 節では，手掛かり語によらない論理構造の把握の仕 方について整理する . 3 節には，いくつかの接続表現に おける接続の強さについて説明を行う．4節には，このよ うにして得た論理構造の図式表現として統計関係者以外 にはあまり知られていない星座グラフを用いることを試 みる. 適用に際し，若干のカスタマイズを必要とする . 5 節には，毎日新聞の CD-ROM を用いて，2006 年のコラ ム (余録) および社説に適用した結果について紹介する。 全体としての傾向に加え，着目した小論文の性質や振る まいについても同時に知ることができる . 6 節はまとめ とし，今後の課題について言及する .

\section{2. 手掛かり 語によらない論理構造}

\section{$2 \cdot 1$ 接続表現による方法}

自動要約の分野でも, 要約文の生成に, すなわち文章 構造の把握のために手掛かり語に多く頼ってきた [Mani 01, Marcu 00] .ここでいう手掛かり語とは，主に順接や 逆接の接続表現のことを指す . [野矢 97] によれば, 順接 の論理として以下の 4 通り存在するという

付加：主張を加える接続関係である. 典型的には「乥し て」で表される.他にも「しかも」や「むしろ」な どがある．省略されることも少なくない．

解説: 典型的には「すなわち」,「つまり」,「言い換えれ ば」「要約すれば」といった接続表現で表される接 続関係である。

論証：理由と帰結の関係を示す.理由を示す典型的な接 続表現には,「なぜなら」,「光の理由は」などがあり， 帰結を示すものとしては「「光れゆえ」「したがって」， 「だから」,「つまり」などがある .

例示: 典型的には「たとえば」で表される接続関係であ り，具体例による解説，ないし論証としての構造を もつ.

逆接の論理としても以下の 4 通りが存在しているとし ている。

転換： ある主張 A に対して対立する主張 B が続けられ るとき，Bの方にいいたいことがくる接続関係をい 
う.一般に「A だが $\mathrm{B} 」, 「 \mathrm{~A} ，$ しかし $\mathrm{B} 」$ という表 現をとる

制限：上記において，A の方にいいたいことがくる接続 関係をいう．いわゆる「ただし書き」であり，典型 的には「ただし」や「もつとも」などがある .

譲歩：転換の一種とみることもできるが , 譲歩の場合は 対話的構造か現われる.典型的には「たしかに」「た ちろん」などである .

対比：典型的には「一方」「他方」「乥れに対して」と いった接続表現で表される接続関係である。

\section{$2 \cdot 2$ 接続表現によらない方法}

前項の接続表現が用いられたときは，確かに光れに対 応する論理を構成するであろう．しかし, 上記の接続表 現がない場合でも，接続の論理は起こり得る．弚れは明 示的な接続表現が省略された場合であって，光のことを 検出/判断する方法として以下の 2 つが考えられる.

一つ目は前の段落を受ける指示代名詞を検出すること である . 著者らは形態素解析として茶鉒を用いているが， 段落の最初の文において最初の句 (文頭から最初の句点 との間) に指示代名詞が存在したときに, 前の段落ある いは前の段落中のなにかを示す指示代名詞であると判断 する.

もう一つの方法は文末モダリティ分析である．モダリ ティ(modality) とは, 時制や態などとは違って, 文か指 す内容に対する話し手の判断や心的態度をいう.「〜すべ きである」や「〜とみられる」などが光れに当たる．

日本語の場合はモダリティが主に文末に位置するため， 兴の識別は比較的容易である．本稿における実験では， 各文の終端から文頭方向に 10 文字を切り取り，予め登録 してあった文末パターンのデータベースと照合すること でモダリティの識別を行っている . 文末モダリティの分 類体系の構築にあたっては, [日本語記述文法研究会 03] の体系を部分的に修正して採用した .

現在，文末モダリティとして 37 個を用意しているが， 順接を示す文末モダリティには例えば以下が挙げられる . 付加: 「〜(は|も) 弚うである」

解説: 「〜といえよう」,「〜とまとめられる」,「〜と要 約できる」

論証: 「〜からである」「(などの) 理由による」,「〜だ と考えられる」

例示: 「挙げられる」,「列挙できる」

一方，逆接における文末モダリティは考えない，逆接 の論理を逆接の接続表現なしに展開することは実質上想 定しにいからである.言い替えれば，逆接の論理が展開 されるときは，接続表現が省略されることはなく，した がって文末モダリティを考える必要がないと判断する .

もっとも，(最初の文の) 最初の句に指示代名詞があっ て，逆接でもない場合は起こり得る。この場合は最も弱 い順接の接続関係である「付加」と見なすこととする .
さて、「前の段落を受ける指示代名詞」も存在せず,「文 末モダリティ処理によっても順接の分類ができない」場 合も起こり得る.このような場合は，指示代名詞が存在 する場合に比へ順接の程度がより弱いと判断されるので， 「付加推定」と名付け, (後述する) 接続表現にかかる重み の量を低減する

以上を整理し，小論文のような明示的な構造を持たな い文章の論理構造を以下の手順により決定する .

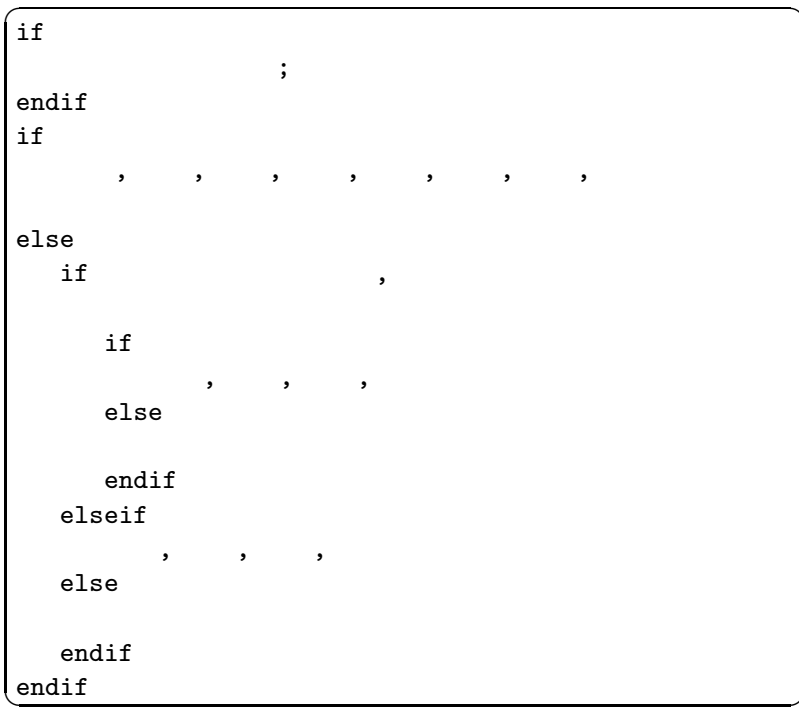

\section{$2 \cdot 3$ ラベル付けの実例}

一つのコラムで, 8 通り全ての接続論理が出現するこ とは極めて稀有であろうし，仮にあったとしても光れが コラムとしての体裁をなすとも思われない，乥こで，逆 接の表現が 2 回出現する例として, 毎日新聞の 2006 年 5 月 13 日付けの余録を以下に示す.説明の都合上, 段落 番号を [] で示す.

余録: 昔の中国では北斗七星が... [1] 昔の中国では北 斗七星が死をつかさどり，南斗六星が生をつかさどると いう俗信があったようだ．4世紀に書かれた伝奇集「捜 神記」には，碁を打っていた北斗星と南斗星に酒食を献 じて寿命を延ばしてもらうという話がある.[2] 易者に若 死にの相があるといわれた少年は，卯（う）の日に桑の 大樹の下で碁に熱中する 2 人に酒を注ぎ，肉を差し出す． 返礼に南斗星は, 北斗星の閻魔帳 (えんまちょう) の「十 九歳」の文字に上下置換の印を書き入れて，90歳まで 生きられるようにしてくれたのだ.[3] さてどこかで碁を 打つ神仙の閻魔帳には, 自分の寿命はどう書き込まれる のだろう . 決まった寿命も書きかえられることがあるの だろうか .こんな空想か顗をよぎるのも，本紙のキャン ペーン企画「救えた命」で, 患者の生命は運まかせとも いえる救急医療の現状を読んだからである.[4] 关れに よると全国で年間 10 万人以上もの重症救急患者が，十 分な治療のできない病院に搬送されている可能性がある という．むろん治療の遅れが死につながるようなケース だ. 背景には救急隊員が患者の重症度を判断して搬送先 
の病院を選ばねばならない制度の実態があるというのだ． [5] 対応能力によって3ランクに分かれる救急病院だが， 救急隊員はどのランクの病院に搬送するかを決めねばな らない.だが症状の判断は難しく，重症患者の35\%を 救急隊が中軽症と見ていたとのデータや，運び込まれた 重症患者のうち救急隊が重症と思っていたのは約 2 割と の調査もある.[6] まるで人の寿命を決める神仙のよう な役割を押しつけられる救急隊員もたまらない．ここは どんな症状にも対応できる救急センターにまず運ゔ仕組 みがほしい，寿命はやっぱり制度の不備ではなく，神樣 が決めてくれるのがいい .

このコラムの各段落に付けた接続関係のラベルは順に [2] 付加推定, , [3] 転換, [4] 付加, [5] 転換, [6] 付加 推定, となる。

段落 [1] は最初の主張なので, 接続を示すラベルはな い.段落 [3] は文頭の「さて」が「転換」を示す接続表 現になる.段落 [4] は最初の文の最初の句にある「光れ によると」の「弚れ」が前の段落の表現を受けていると判 断され、付加」とラベル付けされる．段落 [5] では「だ が」は文頭にはないが, 最初の文の最初の句の最後にあ るので, 最初の句の内容を転換しており,「転換」と判断 される.つまり，逆接の接続表現においては，弚の表現 が最初の文の文頭あるいは最初の文の最初の句中にあれ ば，弚れに対応したラベルを付けることとしている．段 落 [2] と [6] については, 文末モダリティ処理を行っ ても，適当な分類を適用することができず，「付加推定」 としているが，これらの判断は適切であることが確認で きるだろう .

\section{3. 接 続 の 強さ}

\section{$3 \cdot 1$ 順接}

最も単純な順接の構造は，順に主張を「付加」してゆ くものである.しかし，一般的に単に主張を次々に付け 加えていくだけでは議論にならない「「何をいっているの か」を更に敷衍したり，具体例を挙げていって解説する こと，乥して「なぜそう言えるのか」を根拠づけること が必要となる [野矢 97] .すなわち, 順接の議論の構造と は，主張すること，主張を「付加」すること，「解説」す ること，例示」すること，論証」することによって成り 立っているといえる

しかし乥の議論の流れ，すなわちある主張がなされ，光 れが保持され，光れを踏まえた上で議論が展開されてゆ くということを考えた場合に，弚の接続関係には自ずと 強弱がある。たとば，「付加」は主張を付け加える接続 関係であるから，論理的には最も弱い接続関係であると いえる.このことは，しばしば「付加」の明示的な接続 表現が省略されることからもわかる「解説」は，さらに 細かく「要約」，敷衍」,「換言」に分類されるが，とり あえず大づかみな目安としては, 主張 $\mathrm{A}$ と主張 $\mathrm{B}$ が等
しい $(\mathrm{A}=\mathrm{B})$ ということを示している.「論証」は，主張 $\mathrm{A}$ が主張 B の根拠になっている $(\mathrm{A} \rightarrow \mathrm{B})$ ことを示して いるので, 最も順接の接続か強いといえよう「例示」は， 具体例による解説なのか論証なのかは一般には明確では なく，むしろ解説と論証の中間的な，あるいは両方にま たがる位置にあると見なされる．

これより順接の接続関係には, 以下の強弱関係がある といえる

付加 $<$ 解説 $<$ 例示 $<$ 論証

\section{$3 \cdot 2$ 逆 接}

$\S 1$ 転換と制限

一般に「Aだが, B」「Aしかし B」といった転換の表 現において，多くの場合にBの方に言いたいことがくる． つまりまず主張 $\mathrm{A}$ が提示され，产の後で光れと対立する 主張 B に乗り変わることになり，これは議論の流れが最 も大きく変わる接続関係ということができる .

一方「A ただし B」という構造の「制限」では，あく までも A の方に主張があり B は乥れを補足的に制限す るにすぎない，したがって，転換と制限については，

制限 $<$ 転換

の強弱関係があるといってよい .

$\S 2$ 譲歩と対比

讓歩は転換の一種とみなすことができる . 単なる転換 と讓歩の差は微妙であり，したがって接続の強弱の程度 もほぼ同じであるとみなしてょいであろう .

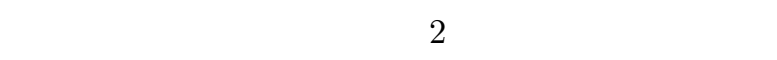
と相違点を持つ. 相違点がない場合は対比にならないの は当然であるが, 共通点を持たない場合もやはり対比に ならない. 対比において示される共通点は, 弚こで課題 にされていることが何であるかを示し，相違点は光の話 題について何がいいたいのかを示している．したがって 対比は制限に比べれば, 対比のポイントが存在するとい う点で逆接の程度が大きいと考えることができる。

以上の議論より，逆接の論証の強弱関係は以下のよう になると考えられる

制限 $<$ 対比 $<($ 裹歩 $=$ 転換 $)$

\section{$3 \cdot 3$ 論理の繋がりを示すポイントの付与}

議論の流れを掴むとは，樣々な主張の票がり具合を把 握することに他ならないから，これら順接/逆接の論理 がどのような順番で繋がっているかを見れば，弚の論理 展開を把握することができるであろう．いま，順接を+ のポイント，逆接を一のポイントとし，前項で述べた順 接/逆接の論証の強さに応じて,+4 から -4 のポイント を付与することを考える。

便宜的であるが, 順接については, 付加推定 $(+1)$, 付 加 $(+1.5)$, 解説 $(+2)$, 例示 $(+3)$, 論証 $(+4)$ とし, 逆接 
については, 制限 $(-2)$, 対比 $(-3)$, 譲歩 $(-4)$, 転換 $(-4)$ を与える . 最初の段落にどのようなポイントを与えるか は難しいところであるが，第 2 段落に「付加」がついた ときには, 論理の流れが変わらない一方, 明示的な「付 加」はその論理を補強する意味あいをもつので, ここで は「付加」よりもわずかに弱い「付加推定」と同じポイ ントを与えることとする．

2.3 節の事例では文章の展開が，第 2 段落以降，

付加推定, 転換, 付加, 転換, 付加推定

となっているので, この場合，最初の段落の分も含め， $+1,+1,-4,+1.5,-4,+1$ と記録する .これにより，全体 の論理の繋がりを把握することができる．また，話題の 転換の程度もわかるようになる。

その際に, 単に $(+4) \sim(-4)$ のポイントを付与するだ けでなく，光のポイントに対応する段落の文字数 (談話 量) を考慮することが大切である . 2.3 節の事例では炎の 段落毎の字数は [1] 98 文字，[2] 116 文字，[3] 122 文 字，[4] 125 文字，[5] 126 文字，[6] 99 文字であり，この 字数に応じた総和を 1 とする重みとして $98 / 686=0.14$, $0.17,0.18,0.18,0.18,0.14$, 論理構成を示す変量に 掛けることは妥当であろう。

\section{4. 星 座グラフ}

星座グラフは多変量データのグラフ表現法の一つとし て , [Wakimoto 78] により考案されたグラフである .

作成の手順は以下の通りである .

- $p$ 変量の観測データを $\boldsymbol{x}=\left(x_{1}, x_{2}, \cdots, x_{p}\right)$ とする .

- $\boldsymbol{x}$ の各要素を区間 $[0,1]$ に規準化する: $y_{i}=f_{i}\left(x_{i}\right), \quad i=1,2, \cdots, p$

•さらにこれらを区間 $[0, \Pi]$ の角度に変換する: $\xi_{i}=y_{i} \pi, \quad i=1,2, \cdots, p$

- $\boldsymbol{x}$ の各要素にかかる変量の重みを $w_{i}$, ただし $w_{i} \geq 0$, $\sum_{i=1}^{p} w_{i}=1$ とする .

- 原点 $(0,0)$ を出発点として,「角度 $\xi_{i}$ の方向に長さ $w_{i}$ だけ進む」という操作を $i=1$ から $p$ まで繰り返 し，最終到達点に印を付ける．この点は原点を中心 とする長さ1の半円の内部にある .

・ $n$ 個のデータ $\boldsymbol{x}_{1}, \boldsymbol{x}_{2}, \cdots, \boldsymbol{x}_{n}$ について行えば, 半円 内に $n$ 個の点がおちる .

これらの手順を示したのが図 1 である .

区間 $[0,1]$ に規準化する関数 $f_{i}(x)$ としては, 第 $i$ 変数 の $n$ 個の観測值の最大值 $M_{i}$ と，最小值 $m_{i}$ を用いて

$$
f_{i}(x)=\left(x-m_{i}\right) /\left(M_{i}-m_{i}\right)
$$

とすることが多い .

このグラフでは原点と最終到達点を結んだ直線の向き でおおよ光の方向 (傾向) がわかり, 原点と最終到達点と の距離で $x_{i}, i=1, \cdots, p$ のバラツキの程度がわかる; $x_{i}$

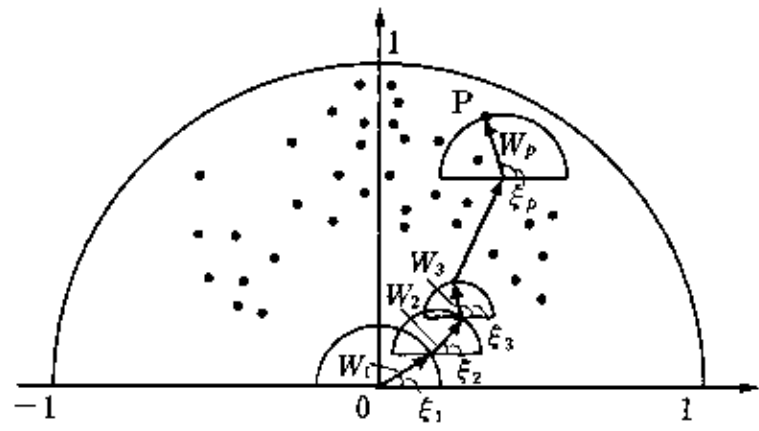

図 1 星座グラフの概念図

のバラツキが小さければ, 角度 $\xi_{i}$ がほぼ同じなので, 最 終到達点は半円周の近くに落ちる.一方, $x_{i}$ のバラツキ が大きければ，角度 $\xi_{i}$ が樣々になり，最終到達点は半円 周内の中心寄りに落ちることになる．また着目したデー タxについて，光の経路を折れ線で書けば，光のデータ の全体における位置と, 最終到達点への過程がひと目で 理解することができる .

このように星座グラフでは, 全体としての分布と, 着 目したデータについての詳細の両方の把握に利用できる .

\section{5. 毎日新聞のコラム/社説による例}

毎日新聞 CD-ROM2006 年版より，光こに掲載されて いるコラム (余録) 365 編と社説 730 編 (1日 2 編) を抜き 出す．コラムや社説では段落が明示されているので，段 落毎に乥の接続関係を示す「付加 (推定)」,「付加」,「解 説」,「例示」,「論証」,「転換」,「制限」,「讓歩」,「対 比」のラベルを付け，3 節で決定した接続関係に応じた $+4 \sim-4$ のポイントを付与する .

各段落にかかる重みは, 段落の分量 (文字数) に応じて 総和が 1 になるように按分する.これは, 誰にでも納得 しやすいだろうという著者の判断による .

星座グラフのR によるソースコードは [青木 07] によっ て公開されているが, これを谷のままの形で利用するこ とはできない . なぜなら通常の星座グラフでは, 重み $w_{i}$ が各データに対して共通であるが, 本事例では, コラム/ 社説ごとに光れが含む段落の数 $(p)$ が一定でなく，この ため重み $w_{i}$ がデータ毎に異なるからである .これに対 応できるよう, ソースコードに若干の修正を加えた 。

また，着目したデータの経路が表記できるように，最 終到達点のみマークする場合と, 経路も表記するのとが 選択できるよう関数の引数で指定できるように修正した .

実際の解析結果を図 2 に示す . (a) はコラム (余録; 700 字，365 編)の結果であり，(b) は社説 (1,200 字，730 編) の結果である . 2006 年の最初の余録，および社説につい ては途中の経路を示した . 経路が一連の論証の進め方 , す なわち論理構造を示していることになる。 


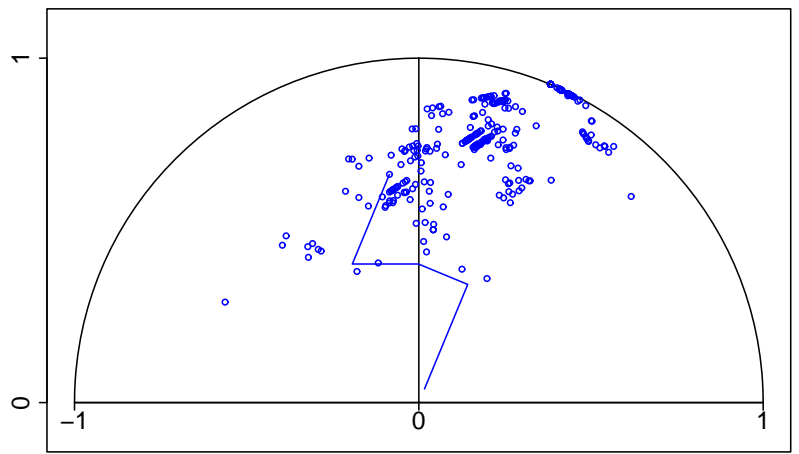

(a) コラム (余録; 700 字，365 編)

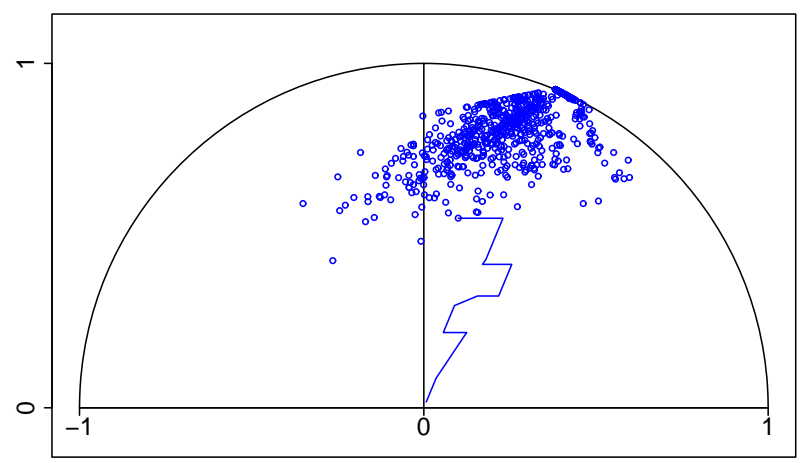

(b) 社説 $(1,200$ 字, 730 編)

図 2 毎日新聞 CD-ROM 2006 年度版

(a)のコラムの結果からは以下がわかる .

・全体として +1 (付加) の方向にデータが落ちており， 「付加」により論理を繋ぐ文章が多いことがわかる．

・逆接の論理を光れに交えることで, 全体のプロット が半円上の右上から左下に移動する; 半円上の左半分 に最終到達点がプロットされる文章も (365 編中) 63 編存在する . 経路を示した文章も关の 1 つである .

(b) の社説についてもコラムの場合とほぼ同じであり， 全体として付加の論理により論証を進めていく文章が大 半であり, 光れに幾つかの逆接の論証を交える書き方が 多いことがわかる .

いままで著者らの開発した自動採点システム Jess で は，接続表現だけに頼っていたために，文字数の少ない コラムでは接続表現が少なく(場合によっては全く存在 せず) 論理構造を把握することが困難であったが , 本稿 で示した指示代名詞や文末モダリティ処理により，接続 表現だけに頼らずに論理構造を把握することができるよ うになった .これによって，文字数の異なる余録や社説 においても，論理の展開の仕方にはさほど違いのないこ とも確認された .
著者らは 2006 年のみならず, $1999-2002$ 年のデータに 対しても適用し，ほぼ同樣の結果を得ている.ただ 2006 年版では, 新聞の活字が大きくなったため，1999-2002 年版に比べ文章量はコラム, 社説ともに 2 割ほど少なく なっている.

\section{6. おわりに}

小論文/エッセイの議論や論理の展開の仕方は, 文章 で述べている多くの主張の動向兴のものであり, 弚れを 要約し可視化したものが, 本稿で提示した星座グラフで ある . 星座グラフは多変量データを記述的に示すきわめ て有効なグラフ表現法である.多くの統計グラフは (統 計理論弚のものが通常の場合ランダムサンプリングに基 づいているために) データの出現順を考慮していないが， この星座グラフでは途中の経路を示すことで, 着目した データの時系列変化が見て取れる.動向情報の要約と可 視化に有効な手段として，情報編篡の分野においてわが 国の統計学者が考案したこのグラフ表現法が広く普及し 活用されることを期待している .

本稿の事例に星座グラフを適用した場合の今後の課題 としては ,

・著者らが開発している Jess への早急な実装と

・ポイント $(+4 \sim-4)$ の合理的な付与の仕方 が挙げられ，現在，検討を進めているところである．

\section{謝辞}

本研究については科学研究費補助金, 基盤研究 (B),「日 本語小論文の自動評価における総合的研究」(課題番号 : 19300292 , 研究代表 : 石岡恒憲) の援助を受けた .

\section{$\diamond$ 参 考 文 献 $\diamond$}

[青木 07] 青木繁伸. 星座グラフ, R による統計処理, http://aoki2.si.gunma-u.ac.jp/R/Constellation.html

[Burstein 98] Burstein, J., Kukich, K., Wolff, S., Lu, C., Chodorow, M., Braden-Harder, L., \& Harris, M.D. Automated Scoring Using A Hybrid Feature Identification Technique. In the Proceedings of the Annual Meeting of the Association of Computational Linguistics, Montreal, Canada, http://www.ets.org/research/erater.html, 1998.

[Burstein 03] Burstein, J. \& Wolska, M. Toward evaluation of writing style: Finding overly repetitive word use in student essays. In Proceedings of the 11th Conference of the European Chapter of the Association for Computational Linguistics, Budapest, Hungary, 2003.

[Deerwester 90] Deerwester, S., Dumais, S.T., Furnas, G.W., Landauer, T.K., \& Harshman, R. Indexing by latent semantic analysis. Journal of the American Society for Information Science, 41 (7), 391-407, 1990.

[Elliot 99] Elliot, S. Construct validity of IntelliMetric with international assessment, Yardley, PA: Vantage Technologies (RB-323), 1999.

[Elliot 03] Elliot, S. IntelliMetric: From Here to Validity, 71-86. In Shermis, M. \& Burstein, J. eds. Automated essay scoring: A cross-disciplinary perspective. Hillsdale, NJ: Lawrence Erlbaum Associates, 2003. 
[Foltz 99] Foltz, P.W., Laham, D., \& Landauer, T.K. Automated Essay Scoring: Applications to Educational Technology. In Proceedings of EdMedia '99., 1999.

[GMA-Council 05] Graduate Management Admission Council. The Official Guide for GMAT Review, 11th Edition, 2005.

[石岡 03] 石岡 恒憲・亀田 雅之. コンピュータによる小論文の 自動採点システムJess の試作, 計算機統計学, 16 (1), 3-18, 2003.

[Ishioka 06] Ishioka, T. \& Kameda, M., Automated Japanese Essay Scoring System based on Articles Written by Experts, Proceedings of the 21st International Conference on Computational Linguistics and 44th Annual Meeting of the Association for Computational Linguistics, Association for Computational Linguistics, 233-240, Available online: http://www.aclweb.org/anthology/P/P06/P06-1030, 2006.

[Landauer 00] Landauer, T.K., Laham, D., \& Foltz, P.W. The Intelligent Essay Assessor, The Debate on Automated Essay Grading, IEEE Intelligent Systems, 15(5), 27-31, 2003.

[Landauer 03] Landauer, T.K., Laham, D., \& Foltz, P.W. Automated Scoring and Annotation of Essays with the Intelligent Essay Assessor, 87-112. In Shermis, M. \& Burstein, J. eds. Automated essay scoring: A cross-disciplinary perspective. Hillsdale, NJ: Lawrence Erlbaum Associates, 2003.

[Mani 01] Mani, I. Automatic Summarization, Natural Language Processing 3, John Benjamins Publishing Co., June 2001.

[Marcu 00] Marcu, D. The Theory and Practice of Discourse Parsing and Summarization, The MIT Press, November, 2000.

[日本語記述文法研究会 03] 日本語記述文法研究会編. 現代日本 語文法 4 一第 8 部モダリティ一,〈ろしお出版, 2003.

[野矢 97] 野矢 茂樹. 論理トレーニング, 哲学教科書シリーズ, 産 業图書, 1997 .

[Page 66] Page, E.B. The imminence of Grading Essays by Computer, Phi Delta Kappan, 238-243, 1966.

[Page 94] Page, E.B. New Computer Grading of Student Prose, Using Modern Concepts and Software, Journal of Experimental Education, 62(2), 127-142, 1994.

[Reed 01] Reed, C.A. \& Rowe, G.W.A. Araucaria: Software for Puzzles in Argument Diagramming and XML, in Department of Applied Computing, University of Dundee Technical Report, 2001.

[Rudner 02] Rudner, L.M. \& Liang, L. Automated essay scoring using Bayes' theorem, National Council on Measurement in Education, New Orleans, LA. Available online: http://ericae.net/betsy/papers/n2002e.pdf, 2002.

[Wakimoto 78] Wakimoto, K. \& Taguri, M. Constellation Graphical Method for Representing Multi Dimensional Data, Ann. Statist. Math., 30, Part A, 77-84, 1978.

〔担当委員 : 小林一郎〕

2007 年 10 月 22 日 受理

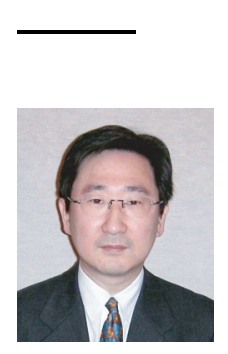

\section{紹 介}

\section{石岡 恒憲(正会員)}

1985 年東京理科大学大学院修士課程工学研究科経営工学 専攻修了. 同年 株式会社リコー (ソフトウェア研究所) 入 社. 1998 年文部省 大学入試センター研究開発部助教授. 組織改編に伴い現在独立行政法人大学入試センター准教授 統計学, 信頼性工学, 情報数理に関する研究に従事. 工学 博士. IEEE Trans. on Reliability 論文審査委員. 日 本信頼性学会 (論文審査委員), 応用統計学会 (編集委員), the World, 25th Edition, 2008 . 